\title{
The Challenges Concerning the Lifestyle Sustainability of the Tapuya Kariri Indigerous People in São Benedito, Ceará
}

\author{
Antonia Vanessa Silva Freire Moraes Ximenes ${ }^{1}$, Marília Araújo Fontenele ${ }^{2} \&$ Aldiva Sales Diniz $^{3}$ \\ ${ }^{1} \mathrm{PhD}$ in geography from Universidade Federal do Ceará (UFC). Professor at the Secretaria de Educação do \\ Estado do Ceará (SEDUC) (Ceará Department of Education) and Universidade Estadual Vale do Acaraú (UVA) \\ in the geography undergraduate course, Sobral/CE \\ ${ }^{2}$ Master in geography from Universidade Estadual Vale do Acaraú (UVA), Sobral/CE \\ ${ }^{3} \mathrm{PhD}$ in human geography (USP). Associate professor in the geography undergraduation and graduation courses \\ at the Universidade Estadual Vale do Acaraú (UVA), Sobral/CE
}

Correspondence: Antonia Vanessa Silva Freire Moraes Ximenes, Universidade Estadual Vale do Acaraú, Brazil. E-mail: vanessafxgeo@gmail.com

Received: May 16, 2020 Accepted: August 10, 2020 Online Published: August 23, 2020

doi:10.5539/jms.v10n2p46 URL: https://doi.org/10.5539/jms.v10n2p46

\begin{abstract}
This literature deals with the conflicts experienced by the indigenous people from the Tapuya Kariri tribe, who live in São Benedito, Ceará, and whose tribe has been suffering to sustain its lifestyle and, consequently, the bond among the people. The relevant factors that inspired the development of this paper are the need for discussing the challenges faced by the Tapuya Kariri people as well as listing the involved parts in fights for lands, which are holy in their majority. Thus, the emphasis is on the principal issues involving the indigenous people and those with whom they relate in places the consider to be sacred, on the complexity involving these social interactions and on the confrontation resulting from the struggle to sustain the lifestyle and uniqueness of the abovementioned people.
\end{abstract}

Keywords: sustainability of lifestyle, Tapuya Kariri indigenous people, São Benedito/CE

\section{Introduction}

Historically, the indigenous people have established a relationship with the ground different from that of the white man. They only take what is essential in the land, that is, the characteristics that make land to be land. Landowners, in turn, take what generates profit. Thus, the approached relationship between squatters and indigenous people is an attempt to understand the naturalization feeling the indigenous people concerning the land and their struggle.

Recalling that ontology was proposed by Aristotle (1984) in his book called Metaphysics, which is the study of being qua being, he seeks, in this way, the reason why all things or beings are what they are. Thus, when analyzing the subjects of this research, it is possible to understand that the indigenous village called Aldeia da Gameleira, which is in the border between the municipalities of Carnaubal and São Benedito, makes up the Tapuya Kariri population.

According to information from the Instituto Brasileiro de Geografia e Estatística (Brazilian Institute of Geography and Statistics, IBGE, 2010), the municipality of Carnaubal is home to the largest indigenous population among those located on the Ibiapaba plateau, in the northwestern Ceará. Despite living in the borderline between the abovementioned municipalities of Carnaubal and São Benedito, the Tapuya Kariri people maintain a close relationship with the second one, thus, considering themselves to be citizens from São Benedito since their economic, political and social events happen in this city. Besides, they have developed feelings for that place and an identity relationship.

Currently, there is a series of conflicts because of the relationship the Tapuya Kariri people have established with the land. However, these conflicts involve not only small and medium farmers, who are seen as squatters by the indigenous people, as we refer to these farmers here in this work. The struggle for recognition of the land possession defended by the indigenous people is expanding to include the inhabitants of the quilombo village of Sítio Carnaúbas II, with whom they also dispute the territory. The reason for the clashes is the difference in the 
way land is perceived, that is, squatters use the areas where the Tapuya Kariri people use to meet with their gods. The soil depression (holes) characterizes these sacred areas, which represents places where they can meet with their ancestor. However, landowners prevent these people from accessing these holes. As a result of this avoidance, the Tapuya Kariri people organize continuous actions to retake their holy lands. Therefore, they seek unity among themselves and the preservation of cultural and traditional aspects through the relationship with the ground.

However, there are challenges in the pursuit of sustainability, for example, farmers built fences as a way to prevent people from accessing those places, but the indigenous people cut them down. This action causes numerous threats, makes the dispute and the pursuit of legitimization in the right to the land even tenser. Discussing such issues in their complexity led to the proposition of this research that seeks to list challenges, desires and the daily struggle of the Tapuya Kariri people in defending the sustainability of their beliefs, relationships and traditions.

Besides, this paper seeks to understand the difference between the thought of the supposed landowners and the Tapuya Kariri people's interests, who lives in Carnaúba II, São Benedito, also known as Aldeia da Gameleira, an environment marked by conflicts. The conflicts concerning the territorial dispute have provoked resistance, thus, impelling the authors of this work to adopt a hermeneutic view of the strategies used in the fight for rights and cultural affirmation.

\section{The importance of establishing limits in the indigenous territory for the sustainability of their identity as people}

Since the event known as the discovery of Brazil, the encounter between different worlds has shown for all that the way of perceiving the land can be very diversified, which generates conflicts that highlight the difference in values and meanings given to these places.

For the indigenous people, the ground means home and is a mythical place with cycles and time. The natives did not see the land as private property nor as something to obtain profit. For the colonizers, the ground means achievement and the mark of the king. Almeida (2010) makes people understand that, for a long time, Europeans reduced the indigenous people to mere representatives of the rights of the settlers, thus, converting them into slaves, who were already available in Brazil at the disposal of European exploitation that used them as their hegemonic interests. This way, the natives were useful in defending and conquering territories against tribes that offered threats to Europeans and in exploring new lands unknown to Europe.

When they no longer favored European interests, the colonizers usually sent them to villages distant from their lands, where they would live with people from other tribes, at times enemies. Otherwise, colonizers forced them to marry white people or black slaves so that they get a new culture and stop resisting.

Through his ideas, Almeida (2010) makes people notice that in the condition of slaves, the Brazilian indigenous people were persecuted and led by circumstances to abandon their culture, religion, habits and other identity aspects. Thus, they left their essence behind and disappeared from history. This dismantling and genocide of the natives are the results of the historic poor distribution of Brazilian lands, which date back to the colonial period when the Portuguese disregarded the presence and right to land that of their natives. Then, they divided the country into large lots of land and granted these lots to Portuguese colonizers who, in turn, would only have the task of occupying and making them productive. In the pursuit of escaping from the oppression and persecution suffered by the settlers, the surviving indigenous people started denying their identity in exchange for their survival. In addition to this strategy, which emerged spontaneously, there were cases of miscegenation and incorporation of aspects related to European culture.

Therefore, the process of passive domination has given many indigenous people no option for survival other than acculturation. Such silence favored the writing of a document stating that, in Ceará, there were no more indigenous people since their descendants no longer had the phenotype of their ancestors nor their lifestyle. According to Alegre (2002), in the text of that document, it was read that:

What makes the situation surprising is that, in that short time, there was no awareness of the presence of approximately six thousand natives distributed in about ten municipalities (Alegre, 2002, p. 27).

In his work, Alegre (2002) goes over the paths taken by indigenous peoples. He analyzes their disappearance as a survival strategy, the self-affirmation process and the fight for rights. They tried to rescue and preserve their culture and allocate the land to live and work. Thinking about the cultural reconstruction of these peoples and the ethnology of losses, Oliveira (2004) reports that the northeastern region is the result of an old land system where indigenous organizations worked occasionally. 
Thus, in the northeastern region, the natives were poor backwoodsmen without access to the land. In comparison with the Amazonian natives, who hold a significant part of the ecological niches and territories, the northeastern natives had their areas incorporated by colonizing flows. Therefore, it is up to the public authorities to establish indigenous territories. Still in this context, Oliveira (2004) argues that until recently, the Fundação Nacional do Índio (Indigenous National Foundation, FUNAI) and records of anthropologists considered Ceará, Piauí and Rio Grande do Norte as states without an indigenous population. However, those data fell apart when, in the last decades of the 20th century, an indigenous population arose, demanding the reappropriation of their lands.

Various ethnic groups lived in Ibiapaba, but Sousa (2003) reveals that after the Christian priest Francisco Pinto passes away, in 1607, the place stayed out of the Society of Jesus' missions for a long time. It caused the consequent forgetfulness of the natives and the idea that there were no more indigenous people in Serra da Ibiapaba. After this period, the 1988 Constitution of Brazil declared full rights of the natives over the land, recognizing their rights, their beliefs and their habits, with the union having the responsibility to reschedule their spaces and protect them.

Landowners repeatedly disrespect the indigenous rights despite the law. It is a consequence of capitalism that predominates in the Brazilian countryside and, as a result, it causes attacks on indigenous tribes across the country. Currently, indigenous peoples suffer oppression and violence from farmers and landowners who, not respecting the needs of land use, invade territories in the name of profit, massacring these indigenous peoples many times without any chance of defense. Thus, even though the constitution ensures the land already occupied by indigenous groups, it is FUNAI that approves and demarcates them as indigenous land. Regarding the territories disputed by natives and supposed landowners, Leonardi (1996) states that the land issue in Brazil should no longer be considered only as such, just like in other capitalist countries. The most relevant situations to be considered are that indigenous territories are still quite common in Brazil and that natives were colonizers and colonized at the same time within the same historical process.

The object of this research, the Tapuya Kariri people, is discussed based on the context of people whose struggle is because they lost lands, but who also appropriate land for their use and social survival. They are about 450 people who have been fighting since 2007 to retake their territory in São Benedito, Ceará.

\section{Ibiapaba plateau and the conflict for recognition, sustainability and resistance of the Tapuya Kariri people}

Serra da Ibiapaba, although it is a plateau, is also known as Serra Grande or Serra da Ibiapaba. It is in the northwestern Ceará, on the borderline with the state of Piauí. According to data from IBGE (2010), Ibiapaba has a population of 335,506 inhabitants, distributed in eight municipalities, namely São Benedito, Guaraciaba do Norte, Carnaubal, Croatá, Ubajara, Ibiapina, Viçosa do Ceará and Tianguá. Together, these municipalities make Ibiapaba a reference in the production of vegetables.

According to Sousa (2003), Serra da Ibiapaba was also the stage for Christian missions. It was in this region that remarkable moments of the Society of Jesus mission in Brazil took place (Maia, 2010). According to the history released by the official website of the municipality (2013), the city of São Benedito emerged from a niche in honor of Saint Benedito built by an indigenous leader named Jacó de Sousa Castro. Under the local history, the municipality of São Benedito was born on November 25, 1872. Over time, Felipe Benicio, who was vicar of Viçosa do Ceará, rebuilt a chapel in the same place of the niche in 1941. This chapel later became the main church of the city of São Benedito, inaugurated on December 22, 1951, therefore, ten years after its reconstruction.

Mixed by the indigenous presence and strongly marked by the Tabajara people, the village of São Benedito appears with the first inhabitants of the indigenous people. Therefore, the research object is none other than the indigenous area of the Aldeia da Gameleira, located in São Benedito, with an area of $338.149 \mathrm{~km}^{2}$, being $360 \mathrm{~km}$ away from the capital Fortaleza. Currently, the population sums 44.18 inhabitants (IBGE, 2010). Concerning the geographical location, the limits are Ibiapina to the North, Carnaubal to the South, Graça to the East and Piaui to the West.

With an altitude of 903 meters, the principal biome is the caatinga. Trading and agriculture are the primary sources of income (IBGE, 2010). Regarding the economy, São Benedito also stands out in the production of roses, having one of the largest hubs in the world in this sector. Its exports reach countries like the Netherlands and Italy. Besides, due to its low temperatures, the municipality is today the largest strawberry producer in Ceará.

According to Vozes do Território (2012), they have been living in that region since the 19th century, but their presence was recognized only in the 21 st century when the officialization and recognition of those they consider 
to be their sacred land became an urgent need. According to Almeida (2007), the name Tapuya, which means barbarian in Tupi language, was used by the group to designate all foreigner people. This way of speaking extended to the Portuguese custom that called all non-Tupi groups by Tapuias. In 2008, the Tapuya Kariri people created a statute through the Tapuya Kariri Association. In that document, the group claims to own the land and reports that their descendants would have come from the South of Ceará to Serra Grande before 1988, and inter-ethnic marriages would have occurred populating the are they currently reside. Since they do not have their rights preserved yet, the Tapuya Kariri people continue the struggle to retake their territories, which are also disputed by the quilombo community of Sítio Carnaúbas II, by squatters and by local landowners, who claim to have bought the land.

For the Tapuya Kariri people, the squatters took possession of their places, destroyed the land, ended their rivers by using pesticides, thus, making the entire indigenous population sick. Indigenous people see people the squatters as outsiders and invaders. The situation is not the same anymore. For us to come to the holy places, we have to jump over fences, destroy the forest and face pesticide from the plantations. For us, the land and identity issue are about being free to use the land without being afraid or shot (passage from Carta Vozes da Terra by the Tapuya Kariri people). Leonardi (1996) recalls that natives do not use the land only for subsistence, but they go beyond. The author highlights that the soil sustains the natives' social life and, without it, there would be no link that connects them to their beliefs and knowledge.

With this, it is attributed to the land the meaning of materialized life of the indigenous people. Without this natural resource, as Leonardo Boff would say, indigenous people would feel physically and culturally threatened. At the same time, landowners depend on it to make their money and maintain their dominant position and social status, having what Santos (2009) says is mass culture. According to the author:

Mass culture is indifferent to social ecology and responds affirmatively to the desire for unity and consideration. Having its roots in the land in which it lives, popular culture symbolizes man and his surroundings, embodies the will to face the future without breaking with the place. Its framework and limits are the deep relationships established between man and his environment, but their reach is the world (Santos, 2009).

Thus, to understand better the research object, approaching this concept is necessary since the land and the reason for the conflict are connected.

In geography, different concepts make up the land (Sousa, 2008). Thus, it is closely connected to actions related to power and, consequently, to politics, since the territory has a political character. In this case, conflict is an important variable because it shows relations of possession and struggles for the same object that is the territory.

In the same perspective, Haesbaert (2005) argues that the territory represents power, not only political power but also power itself, that is, domination power and in the symbolic sense of appropriation, as the author defends. Territoriality comes from the concept of land and, according to Raffestin (1993), the territory is the space defined and delimited by power relations in its multiple dimensions. Still, according to the author:

Territoriality then reflects the land experience in all its scope and its multiple cultural, political, economic and social dimensions. People live, at the same time, the land process and product through a system of productivist relationships, understanding that all are relationships of power since there is an interaction among the people that seek to modify both relations with nature and people (Raffestin, 1993, p. 158).

For geography, identity is the territoriality that manifests itself through social, cultural and political relationships in space. Saquet (2008) argues that territoriality encompasses all daily events and gives meaning to certain areas.

This territoriality also relates identity with the relationship of affection in a society that builds a symbolic field. However, territoriality for Raffestin (1993) has particular value because it starts to reflect the dimension experienced by members of civil societies.

\section{Methodology}

The collection of pre-existing statements and prejudices about the theme was essential to develop this research. For this, Gil's words (1995) were helpful, when he says that the set of intellectual or technical procedures, used to get knowledge, is not only a technique but a discovery or unveiling of the reality.

Therefore, in the empirical field, the analysis of the facts, based on the discoveries, was a form of promoting new concepts to improve knowledge about the reality of these indigenous people living in the municipality of São Benedito/CE and their struggle and yearning. This research is qualitative since it aims at improving information and knowing the field. This type of research is also distinguished because it seeks to analyze deeper aspects, 
describing the complexity of human behavior, providing more detailed analyzes of investigations, habits, attitudes and behavioral trends (Marconi \& Lakatos, 2007, p. 269). An exploratory stance was assumed because descriptive researches, along with the exploratory, are the ones that social researchers are usually concerned with, as Gil explains (1995).

For data collection, there was the use of some tools considered to be pertinent to analyze the field, such as participant observation. For Mann (1970, p. 96), this tool is an attempt to place the observer and the observed object on the same side, making the observer a member of the group to experience their experiences and work within the system reference point. Semi-structured interviews were also of great importance in the research, which helped a lot in the understanding of the more specific processes, thus allowing the entrance in questions in a more in-depth way. For Marconi and Lakatos (2007), the interview is a meeting between two people so that one of them obtains information about a specific issue through a conversation of a professional nature (Marconi \& Lakatos, 1996, p. 84).

The conversation circles are also one of the methodological procedures adopted in the research, constituting itself as an auxiliary tool based on the previous search by the leaders of the researched indigenous community. Through this tool, it was possible to get in-depth knowledge about their struggle, its causes and conflicts. Thus, the dialogue established with these peoples sought to give voice to the difficulties they suffer when seeking the sustainability of their lifestyle. This way, they can perpetuate their lives and works in the longed-for indigenous land.

\section{Conclusions and Future Research Orientation}

Given this, it is possible to understand the different perceptions that one has about the same land, which assumes the category of a holy place for the Tapuya Kariri people, who seek the right to possession and recognition of these lands as being a heritage. With this, they could maintain and perpetuate their habits and culture as a people. The objective of this possession goes beyond any notion of economic and financial value that the land may have, but rather, their sustainability and uniqueness are at risk as indigenous people descended from a tribe that overcomes challenges today to maintain its unity character.

The different meanings and values that the land represents to other cultures and peoples come from their unique ways of perceiving the world around them. It is typical of these peoples who have different cultures from which the burden comes symbolic attributed not only to the land but to the possibilities that they offer to each people, culture, belief or religion.

\section{References}

Alegre, S. P. (2002). From ignored to recognized: the "turn of indigenous people in Ceará". In J. Pinheiro (Ed.), Ceará light land, indigenous land: history, presence, perspectives. Fortaleza: Federal Prosecution. $6^{a}$ Coordination and Review Chamber. FUNAI; IPHAN $/ 4^{\mathrm{a}}$ Regional Superintendence.

Almeida, M. R. C. d. (2010). Indigenous People in the History of Brazil (p. 168). Rio de Janeiro: Ed. FGV.

Aristoteles. (1984). Metaphysics (Books I and II). São Paulo: Abril S.A. Cultural.

Boff, L. (2009). The Earth Charter and Global Awareness. A view from inside. In P. A. R. Oliveira \& J. C. A. Souza (Eds.), Global Awareness and Religion-The challenges in the 21st century. São Paulo: Paulinas.

Brazil. (2000). Constitution of Brazil. Brasília, DF: Chamber of Deputies.

FUNDAÇÃO NACIONAL DO ÍNDIO (FUNAI). (2007). Retrieved October 5, 2017, from http://www.funai.gov.br/index.php/indios-no-brasil/terras-indigenas

Gil, A. C. (1995). Methods and Techniques for Social Surveys. São Paulo: Atlas.

Haesbaert, R. (2005). From Deterritorialization to Multiterritorialization (pp. 6774-6792). In X Meeting of Geographers from Latin America, 2005, Annals of the X Meeting of Geographers from Latin America.

IBGE. (2010). Instituto Brasileiro de Geografia e Estatística. Census. Retrieved October 05, 2017, from https://censo2010.ibge.gov.br/

Leonardi, V. P. d. B. (1996). Between Trees and Forgetfulness: social history in Brazilian sertões (p. 431). Brasília: paralelo 15 editores.

Maia. L. J. O. (2010). Serra de Ibiapaba - From the settlement to the indigenous village: vassalage and identity in the Colonial Ceará, 8th century. PhD thesis. Fluminense Federal University. Institute of Human Science and Philosophy. Graduation degree in history. Niterói. 
Mann, P. H. (1970). Sociologic Investigation Methods. Rio de Janeiro: Zahar.

Marconi, M. d. A., \& Lakatos, E. M. (1996). Research Techniques: planning and conducting researches, samples and research techniques, drafting, analysis and interpretation of data (3rd ed.). São Paulo: Atlas.

Marconi, M. d. A., \& Lakatos, E. M. (2007). Scientific Metodology (5th ed.). São Paulo: Atlas.

Oliveira, J. P. d. (2004). An etnology of mixed-race natives? Colonial Situation, territorialization and cultural flow. In J. P. d. Oliveira (Ed.), A trip back: etnicity, polices and the cultural redrafting in the indigenous Northeast. Lacerd.

Raffestin, C. (1993). For a Geography of Power. São Paulo: Ática.

Rigotto, R. M. (Org). (2012). Abrasco's dossier (part 3- Pesticide, Popular and Scientific Knowledge: Building an ecology of knowledge). Porto Alegre, November.

Santos, M. (2009). The Space Nature: Technique and Time, Reason and Emotion. São Paulo.

Saquet, M. A. (2008). For a territorial approach. In M. A. Saquet, \& E. S. Sposito (Eds.), Territories and territorialization: theories, processes and conflicts (1st ed., p. 368). São Paulo: Popular Expression: UNESP. Geography Graduation Programm.

Sousa, M. H. M. d. (2003). Mission in Ibiapaba (p. 122). Strategies in the Colony in the 17th and 18th centuries. Federal University of Ceará. Humanity Center. Departament of history. History graduation programm. PhD. Guidance Professor: Dr. Teresinha de Jesus Mesquita Queiroz.

Souza, M. L. d. (2008). The territory: space and power, autonomy and development. In I. E. Castro et al. (Eds.), Geography: concept and issues (3th ed., pp. 77-116). Rio de Janeiro: Bertrand Brazil.

\section{Copyrights}

Copyright for this article is retained by the author, with first publication rights granted to the journal.

This is an open-access article distributed under the terms and conditions of the Creative Commons Attribution license (http://creativecommons.org/licenses/by/4.0/). 